\title{
Study of the Inhibitor Scaling Effect of the Agricultural Water by a Phosphate Fertilizer
}

\author{
Abdallah Hadfi*, Said Ben-Aazza, M’barek Belaatar, Naima Hafid, Ali Driouiche \\ Department of Chemistry, Team "Materials and Physical Chemistry of Water", Faculty of Science, University \\ Ibn Zohr, Agadir, Morocco \\ Email: "hadfiabd@yahoo.fr
}

Received 17 August 2015; accepted 19 October 2015; published 22 October 2015

Copyright $@ 2015$ by authors and Scientific Research Publishing Inc.

This work is licensed under the Creative Commons Attribution International License (CC BY).

http://creativecommons.org/licenses/by/4.0/

(c) ()

\section{Abstract}

The localised irrigation or drop by drop system is a technique which makes it possible to save water, because it ensures a balanced and efficient distribution of water and an effective fertilization. However, this ferti-irrigation system is facing a number of problems hindering the agricultural development. The lack of uniformity of the localised irrigation was observed and found out that it is due to chemical clogging of drippers. Considering the complexity of the composition of the natural water used in micro-irrigation, we started our study by examining the effectiveness of the inhibitor on pure calco-carbonic water with $40^{\circ} \mathrm{F}$, and then moved to explore the natural water of the agricultural region. The Legrand-Poirier-Leroy method allowed us to determine the position of the irrigation water compared to calco-carbonic balance. LCGE (abbreviation of "Laboratory of Chemistry and Environmental Engineering") technique, based on the accelerated formation of calcium carbonate deposit under the effect of a degasification of studied water, enabled us to evaluate the scaling power of this water of irrigation either with or without inhibitor. The experimental results showed the following: in the case of pure calco-carbonic water with $40^{\circ} \mathrm{F}$ and of natural water, the addition respectively of $2 \mathrm{mg} / \mathrm{L}$ and $2.25 \mathrm{mg} / \mathrm{L}$ of phosphate fertilizer completely inhibits the precipitation of calcium carbonate under the conditions of the experiment.

\section{Keywords}

Scaling Power, Water, Irrigation, Calcium Carbonate, Inhibitor, Phosphate Fertilizer

\section{Introduction}

In order to both avoid useless expenses and save environment, watering drip-drip system, also known as micro-

\footnotetext{
${ }^{*}$ Corresponding author.
}

How to cite this paper: Hadfi, A., Ben-Aazza, S., Belaatar, M., Hafid, N. and Driouiche, A. (2015) Study of the Inhibitor Scaling Effect of the Agricultural Water by a Phosphate Fertilizer. Journal of Water Resource and Protection, 7, 1234-1241. 
irrigation, ensures just distribution of the right quantity of water required for each plant. This system is not only inexpensive but also able to save water and guarantee good fertilization. However, this system of localized fertigation faces problems that constrain agricultural development. The lack of uniformity of drip irrigation has been observed and it is due to the chemical clogging of drippers which is leading to a decline in agricultural production [1].

To prevent the precipitation of calcium carbonate met at the level of drip irrigation systems, we have limited ourselves in this study to looking into preventive chemical processes. This procedure followed is continuously injecting chemical inhibitors in small quantities in the pipeline of the irrigation water.

For agricultural application, it's necessary to use scale inhibitors easily assimilated by plants. That's why we chose a product that can play both the scale inhibitor and the role of fertilizer. In our present study, we are particularly interested in studying the effect of phosphate fertilizer. This product available in the local market is currently used as fertilizer. It is available in white solid form. It is used after dissolution in water.

Given the complexity of the composition of natural waters used in micro-irrigation, we studied the effectiveness of the inhibitor phosphate, first of all, in the pure calcocarbonic water at $40^{\circ} \mathrm{F}$ (TCa similar to that of irrigation water, $1^{\circ} \mathrm{F}$ (French degrees) corresponds to $10 \mathrm{mg} / \mathrm{L}$ of dissolved calcium carbonate or $4 \mathrm{mg} / \mathrm{L}$ of $\mathrm{Ca}^{2+}$ ), and then in the natural water for irrigation. The study was carried out in the temperature of $25^{\circ} \mathrm{C}$. It's always proceeded by increasing amounts; the amount of designated tartrifuge for each test was introduced before the start of the manipulation. In all cases, the presence of tartrifuge does not modify the values of the TAC and TCa measured before the start of the experiment. The scale inhibitor of this inhibitory effect is evaluated by the technical LCGE. This method, proposed by Roques et al. [2]-[5], aims at provoking the precipitation of the calcium carbonate by a degassing (displacement of the calco-carbonic balance in the sense of the formation of the calcium carbonate) of the studied water. The statement of the $\mathrm{pH}$ values and the concentration of $\mathrm{Ca}^{2+}$ ion in the course of time, consequently, allow making a description of the kinetics of precipitation. The experimental installation is shown in Figure 1.

\section{Inhibition of Scaling by a Phosphate Fertilizer}

\subsection{Application for Pure Water at $40^{\circ} \mathrm{F}$}

The phosphate fertilizer is a prevalent complex soluble fertilizer in water. It contains $11 \%$ nitrogen in the ammonium form and $55 \%$ phosphorus pentoxide $\left(\mathrm{P}_{2} \mathrm{O}_{5}\right)$. It is a product prepared by the Moroccan Company of Fertilizers and it is widely available in the local market.

The results obtained from the experimental data of the tests on pure calco-carbonic water at $40^{\circ} \mathrm{F}$, adding gradually increasingly quantities of MAP, carried out at $25^{\circ} \mathrm{C}$, are shown in Figures 2-4. The analysis of these curves and kinetic modeling result in the values shown in Table 1.

The analysis of these results made it possible to come up with the following findings:

- The time of germination increases with the concentration of scale preventive. From the concentrations higher or equal to $2 \mathrm{mg} / \mathrm{L}$ (effective concentration) the inhibition becomes total and the precipitation is not observed during the test.

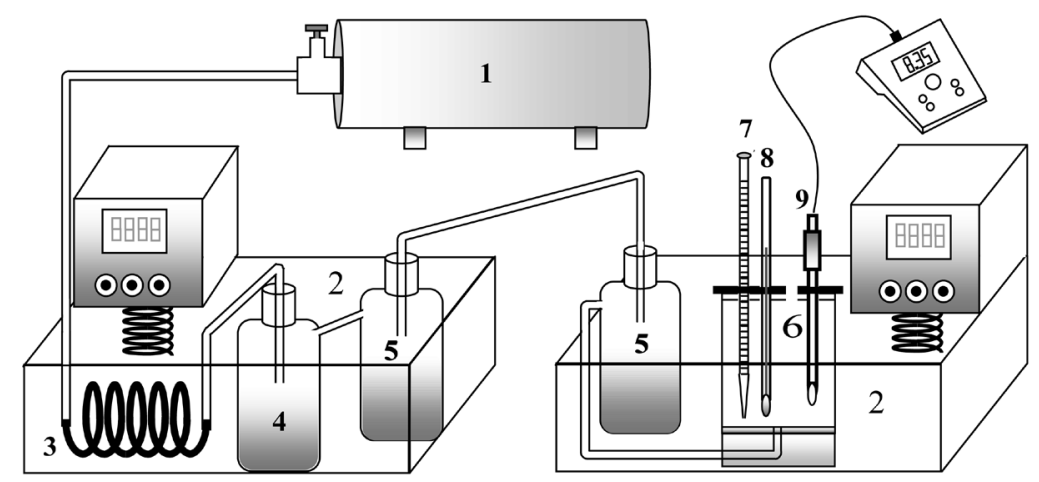

Figure 1. Experimental set-up of the LCGE method. 1. Stripping gas; 2. Thermostat baths; 3. Immersion circulator-heating; 4. Humidifier; 5. Humidity traps; 6. Work cell; 7. Simple taken for dosage of $\left[\mathrm{Ca}^{2+}\right]$; 8. Temperature probe; 9. $\mathrm{pH}$ meter. 


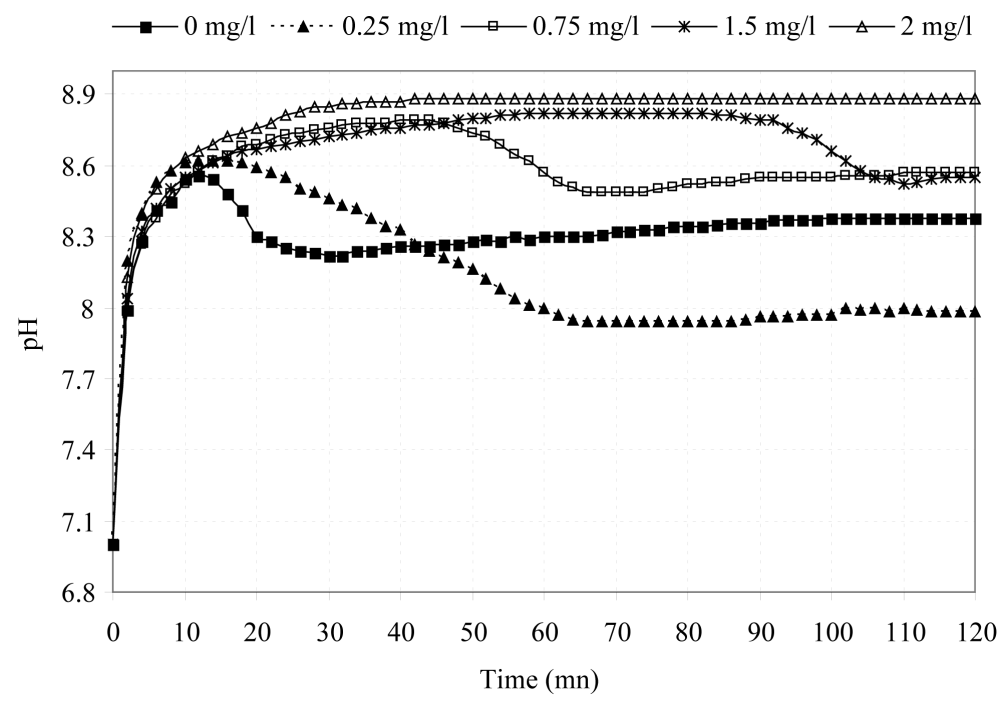

Figure 2. Variation of $\mathrm{pH}$ according to the time of the tests with scale preventer phosphate fertilizer.

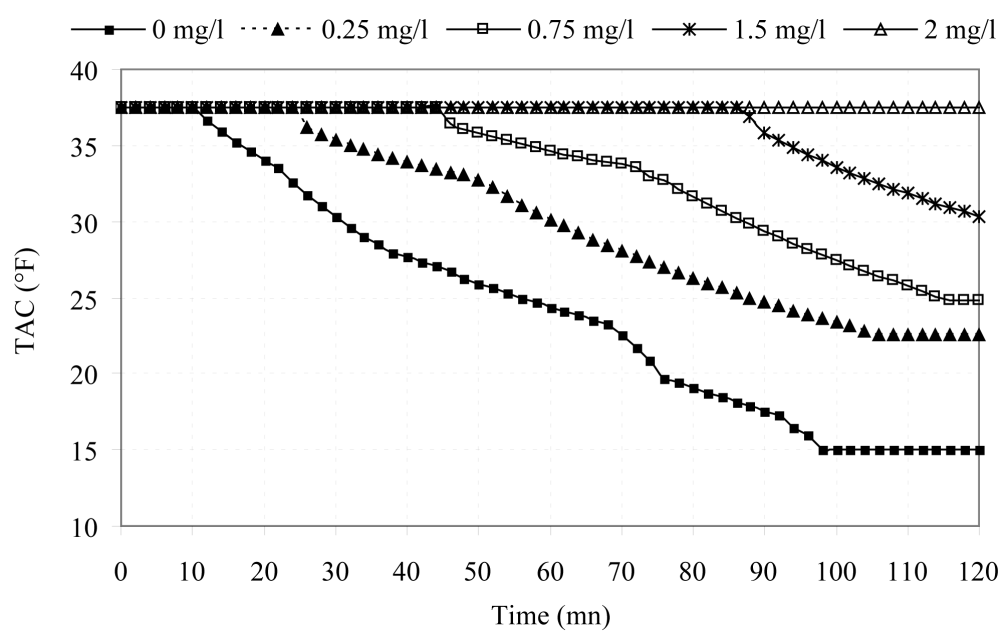

Figure 3. Variation of TAC according to the time of the tests with scale preventer phosphate fertilizer.

- The $\mathrm{pH}$ at the point of germination of the treated water increases with the concentration of the inhibitor, it increases from 8.56 per $0 \mathrm{mg} / \mathrm{L}$ to 8.82 per $1.5 \mathrm{mg} / \mathrm{L}$. The fall in $\mathrm{pH}$ is clearly evident in the test without the inhibitor, whereas when the concentrations are increasing, this fall becomes less remarkable.

- The degree of supersaturation at the time of germination undergoes an increase after the introduction of the scale preventive. It then ranges from 120.39 to test at $0 \mathrm{mg} / \mathrm{L}$ to 224.03 at $1.5 \mathrm{mg} / \mathrm{L}$ of scale preventive.

- The precipitation follows a diffusion model concerning the test without inhibitor. It is modelled by the model of Reddy for tests with the inhibitor.

The scale preventive effect of the ions orthophosphates, in particular ion $\mathrm{PO}_{4}^{3-}$, is due to its surface adsorption on the crystals of calcite according to Reddy [6] and Berner [7]. Simkiss [8] clarified that the ion $\mathrm{PO}_{4}^{3-}$ may locally substitute $\mathrm{CO}_{3}^{2-}$ in the crystal architecture of calcite. This substitution disrupts the electrostatic field due to the difference between the two valence ions thus preventing the formation of a new layer $\mathrm{CO}_{3}^{2-}$ ion and therefore blocks the crystal growth. Stumm et al. [9] have reported the possibility of their side, in a pH which ranges from 6.8 to 8.3, the epitaxial growth of apatite calcite which is also in the sense of the possibility of substitution by $\mathrm{PO}_{4}^{3-}$ ions $\mathrm{CO}_{3}^{2-}$ at the level of implantation surface of the calcite crystal again confirms the dimensional compatibility of the two ions species. 


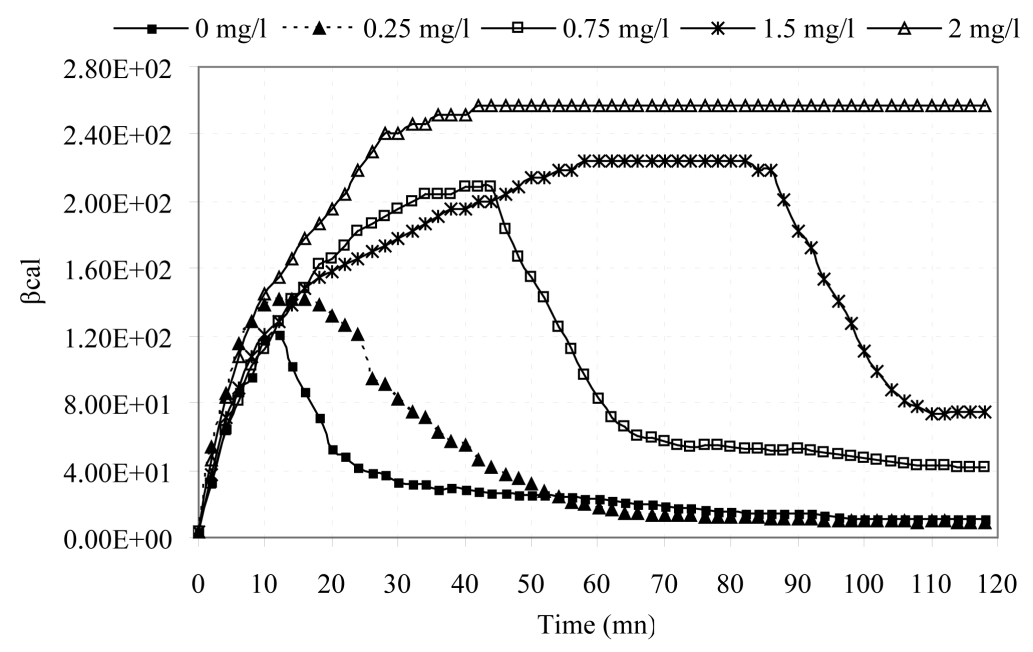

Figure 4. Variation of the rate of supersaturation $\beta$ cal according to the time of the tests with scale preventer phosphate fertilizer.

Table 1. Germination time (Tg), $\mathrm{pH}$ of germination $\left(\mathrm{pH}_{\mathrm{g}}\right)$, supersaturation coefficient overlooked to the calcite $(\beta$ calcite) and precipitation speed of calco-carbonic solution at $40^{\circ} \mathrm{F}$ added increasing quantities of phosphate fertilizer.

\begin{tabular}{ccccccccc}
\hline \multirow{2}{*}{$\begin{array}{c}\text { Concentration } \\
\text { in } \mathrm{mg} / \mathrm{L}\end{array}$} & $\mathrm{Tg}(\mathrm{mn})$ & $\mathrm{pH}$ & $\beta$ cal & \multicolumn{2}{c}{ Diffusional calcite } & \multicolumn{3}{c}{ Reddy calcite } \\
\cline { 6 - 8 } & 12 & 8.56 & 120.39 & $1.41 \times 10^{-2}$ & 0.991 & $0.84 \times 10^{-3}$ & 0.98 \\
0 & 16 & 8.62 & 141.35 & $1 \times 10^{-2}$ & 0.987 & $0.46 \times 10^{-3}$ & 0.989 & $\mathrm{~K}_{\mathrm{D}}\left(\mathrm{mn}^{-1}\right)$ \\
0.25 & 44 & 8.79 & 209.07 & $0.99 \times 10^{-2}$ & 0.877 & $0.46 \times 10^{-3}$ & 0.924 \\
0.75 & 82 & 8.82 & 224.03 & $0.71 \times 10^{-2}$ & 0.823 & $0.24 \times 10^{-3}$ & 0.847 \\
1.5 & - & - & - & - & - & - & - \\
\hline
\end{tabular}

In the case of phosphate fertilizer used here, the phosphate grouping is introduced in the form of monohydrogen phosphate. The small introduced quantities have no significant effect on the $\mathrm{pH}$ of the solution. However, the degassing causes alkalinization of the medium, which stabilizes the anion $\mathrm{PO}_{4}^{3-}$ which can substitute $\mathrm{CO}_{3}^{2-}$ [8]. The electrostatic field is obviously locally disturbed (the phosphate ion carries three loads (-) instead of two for the ion carbonates). The stacking of successive layers of calcite is disturbed and the growth of the germs is thereby stopped.

\subsection{Application to Agricultural Waters}

The Legrand-Poirier-Leroy method is a calculation method based on the thermodynamic equilibrium involving all calco-carbonic species and incorporating the effect of the ionic strength due to other major species. This method has the advantage to be applicable to most types of fresh water and to forecast the characteristics of a water following various treatments of equilibration.

This method allowed us to determine the position of the irrigation waters compared to calco-carbonic equilibrium. Thus, we determined, by means of the software Legrand-Poirier-Leroy (LPLWin), the supersaturation coefficient and the potential quantity of calcium carbonate that should precipitated a liter of water to reach equilibrium.

Table 2 illustrates the physicochemical characteristics and the results of the thermodynamic predictions obtained using the Legrand-Poirier-Leroy method the water. The ionic balance is $0.32 \%$, which is satisfactory. The coefficient of supersaturation is 2.53 , which proves that the type of this water is calcifying and the quantity of calcium carbonate which it must deposit to reach equilibrium is $36.13 \mathrm{mg} / \mathrm{L}$.

The representation of Legrand-Poirier-Leroy applied to water leads to the curves represented on Figure 5. It is 
Table 2. Physicochemical characteristics and results of the thermodynamic predictions of the irrigation water.

\begin{tabular}{|c|c|c|c|c|c|c|c|c|c|c|c|c|c|}
\hline & Value & Unit & $\begin{array}{c}\text { In } \\
\mathrm{me} / \mathrm{L}\end{array}$ & & Results & Unit & Equilibria & Cst. Ca & Marbre & Unit & Equilibrium & Atmosphere & Unit \\
\hline Temperature & 25.0 & ${ }^{\circ} \mathrm{C}$ & & ¿Cation & 13.406 & $\mathrm{me} / \mathrm{L}$ & $\mathrm{pH}$ & 7.06 & 7.17 & & $\mathrm{pH}$ & 9.01 & \\
\hline Conductivity & 1264 & $\mu \mathrm{S} / \mathrm{cm}$ & 1264 & $\Sigma$ Anion & 13.449 & $\mathrm{me} / \mathrm{L}$ & $\Delta \mathrm{pH}$ & -0.4 & -0.29 & & $\Delta \mathrm{pH}$ & 1.55 & \\
\hline $\mathbf{p H}$ & 7.46 & & & Balance & 0.32 & $\%$ & $\Delta \mathrm{CaCO}_{3}$ & & -36.15 & $\mathrm{mg} / \mathrm{L}$ & $\Delta \mathrm{CaCO}_{3}$ & -19.98 & $\mathrm{mg} / \mathrm{L}$ \\
\hline Tot. Hardn. & 53.131 & $\mathrm{mg} / \mathrm{L}$ & 10.626 & $\mathrm{H}_{2} \mathrm{CO}_{3}^{*}$ & 28.869 & $\mathrm{mg} / \mathrm{L}$ & Tot. Alk & 33.0 & 29.385 & ${ }^{\circ} \mathrm{F}$ & Tot. Alk & 33.0 & ${ }^{\circ} \mathrm{F}$ \\
\hline Total Alk. & 33 & $\mathrm{mg} / \mathrm{L}$ & 6.6 & $\mathrm{HCO}_{3}^{-}$ & 400.973 & $\mathrm{mg} / \mathrm{L}$ & $\mathrm{H}_{2} \mathrm{CO}_{3}^{*}$ & 73.322 & 50.825 & $\mathrm{mg} / \mathrm{L}$ & $\mathrm{H}_{2} \mathrm{CO}_{3}^{*}$ & 0.714 & $\mathrm{mg} / \mathrm{L}$ \\
\hline Free $\mathrm{CO}_{2}$ & 20.487 & $\mathrm{mg} / \mathrm{L}$ & 0.466 & $\mathrm{CO}_{3}^{2-}$ & 0.793 & $\mathrm{mg} / \mathrm{L}$ & $\mathrm{HCO}_{3}^{-}$ & 401.96 & 357.767 & $\mathrm{mg} / \mathrm{L}$ & $\mathrm{HCO}_{3}^{-}$ & 351.658 & $\mathrm{mg} / \mathrm{L}$ \\
\hline Calcium & 102.12 & $\mathrm{mg} / \mathrm{L}$ & 5.106 & T.I.C. & 7.052 & $\mathrm{Mm} / \mathrm{L}$ & $\mathrm{CO}_{3}^{2-}$ & 0.314 & 0.356 & $\mathrm{mg} / \mathrm{L}$ & $\mathrm{CO}_{3}^{2-}$ & 24.713 & $\mathrm{mg} / \mathrm{L}$ \\
\hline Magnesium & 67.07 & $\mathrm{mg} / \mathrm{L}$ & 5.52 & $\lambda$ & -0.747 & & T.I.C. & 7.777 & 6.691 & $\mathrm{Mm} / \mathrm{L}$ & T.I.C. & 6.188 & $\mathrm{Mm} / \mathrm{L}$ \\
\hline Sodium & 63.23 & $\mathrm{mg} / \mathrm{L}$ & 2.749 & SatuRatio & 2.53 & & $\Delta$ T.I.C. & 0.725 & -0.362 & $\mathrm{Mm} / \mathrm{L}$ & $\Delta$ T.I.C. & -0.864 & $\mathrm{Mm} / \mathrm{L}$ \\
\hline Potassium & 1.19 & $\mathrm{mg} / \mathrm{L}$ & 0.031 & Type & Calcifying & & Calcium & 102.12 & 87.66 & $\mathrm{mg} / \mathrm{L}$ & Saturatio & 78.0 & \\
\hline Chloride & 128.93 & $\mathrm{mg} / \mathrm{L}$ & 3.632 & satuCO ${ }_{2}$ & 40.41 & & satuCO$_{2}$ & 102.62 & 71.14 & & Type & Calcifying & \\
\hline Sulphate & 67.65 & $\mathrm{mg} / \mathrm{L}$ & 1.409 & & & & & & & & & & \\
\hline Nitrate & 109.40 & $\mathrm{mg} / \mathrm{L}$ & 1.765 & & & & & & & & & & \\
\hline
\end{tabular}

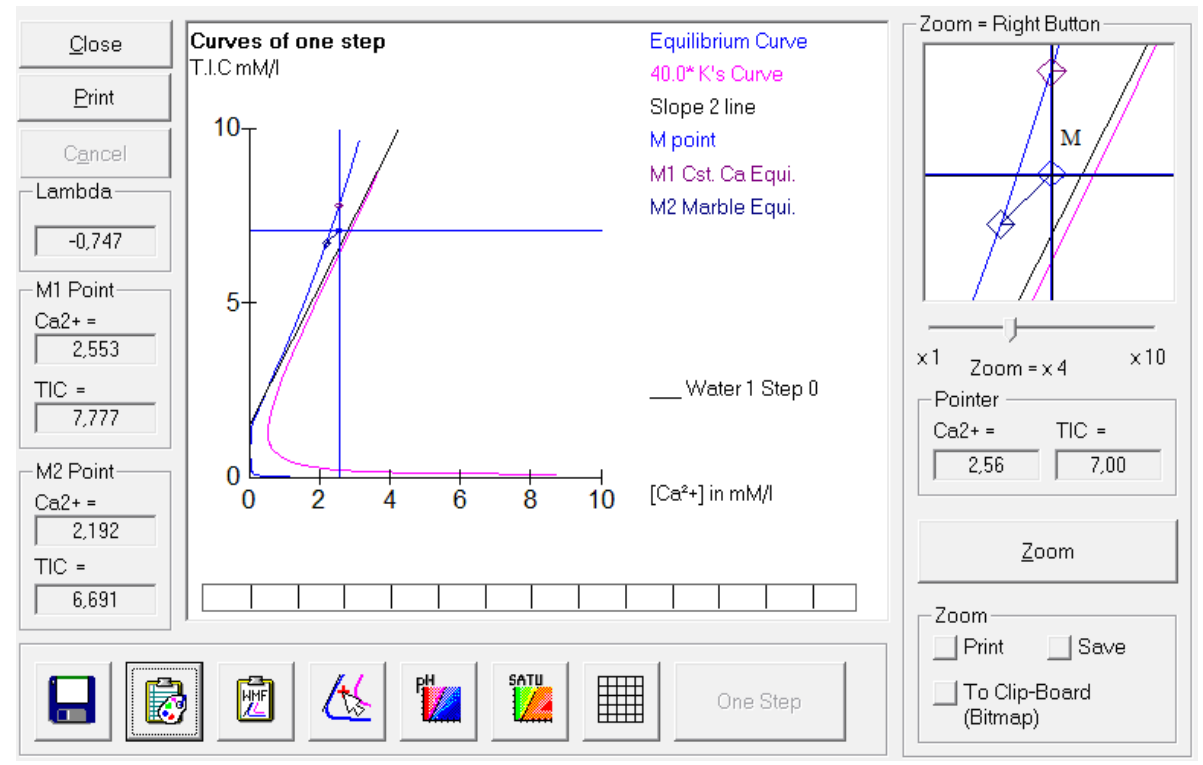

Figure 5. Representation of calco-carbonic balance according to Legrand-Poirier-Leroy of the irrigation water.

noted that the position of the figurative point $\mathrm{M}$ is located in the zone of calcifying water.

Following this study, we were interested in the effect of the phosphate fertilizer on the water of agriculture. This study was carried out by means of the LCGE at a temperature of $25^{\circ} \mathrm{C}$. Figures 6-8 represent curves LCGE of the natural water after adding increasingly quantities of phosphate fertilizer.

The analysis of these curves and kinetic modeling leads to the values presented in Table 3.

Indeed, we notice that in the presence of the chemical inhibitor, the curves of precipitation of calcium carbonate undergo modifications:

- The time of germination is in clear increase compared to the control test. Scaling is completely inhibited for a concentration $2.25 \mathrm{mg} / \mathrm{L}$, under the conditions of the experiment. 


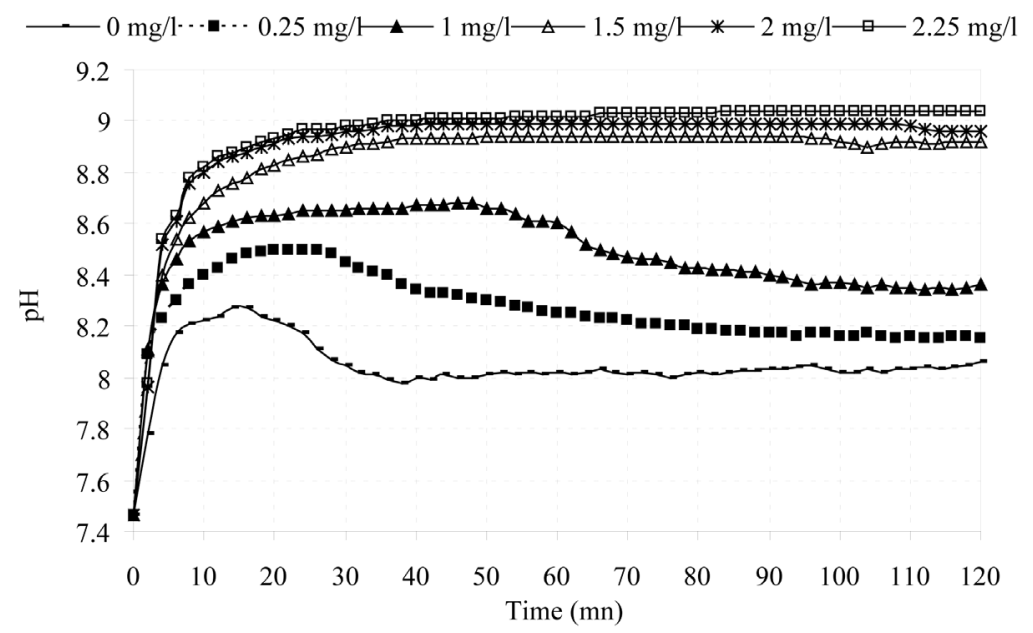

Figure 6. Curves $\mathrm{pH}$ according to the time of the tests with natural water added with the increasing concentrations in phosphate fertilizer.

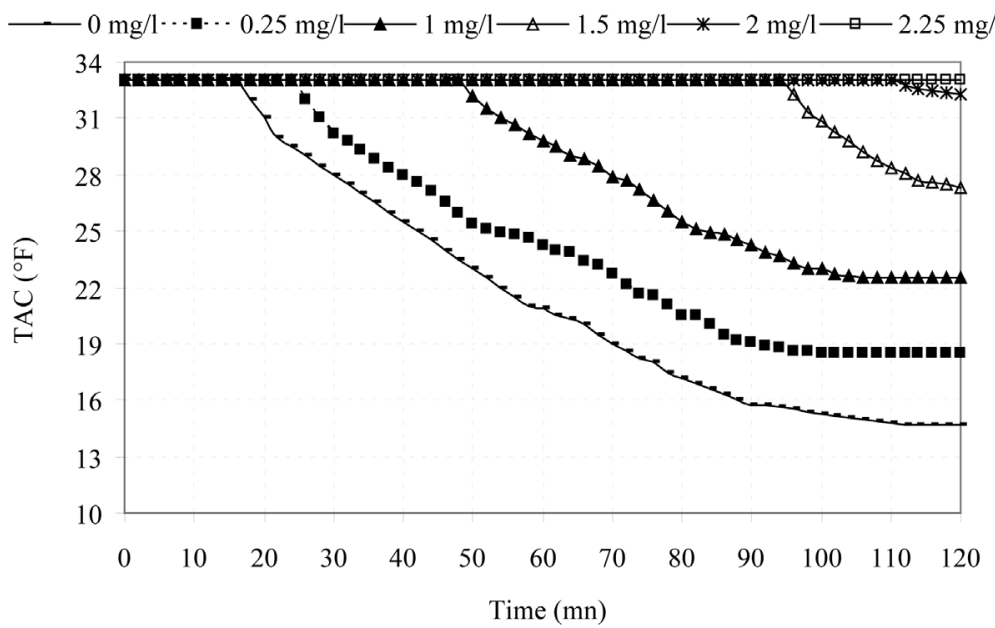

Figure 7. TAC curves according to the time of the tests with natural water added with the increasing concentrations in phosphate fertilizer.

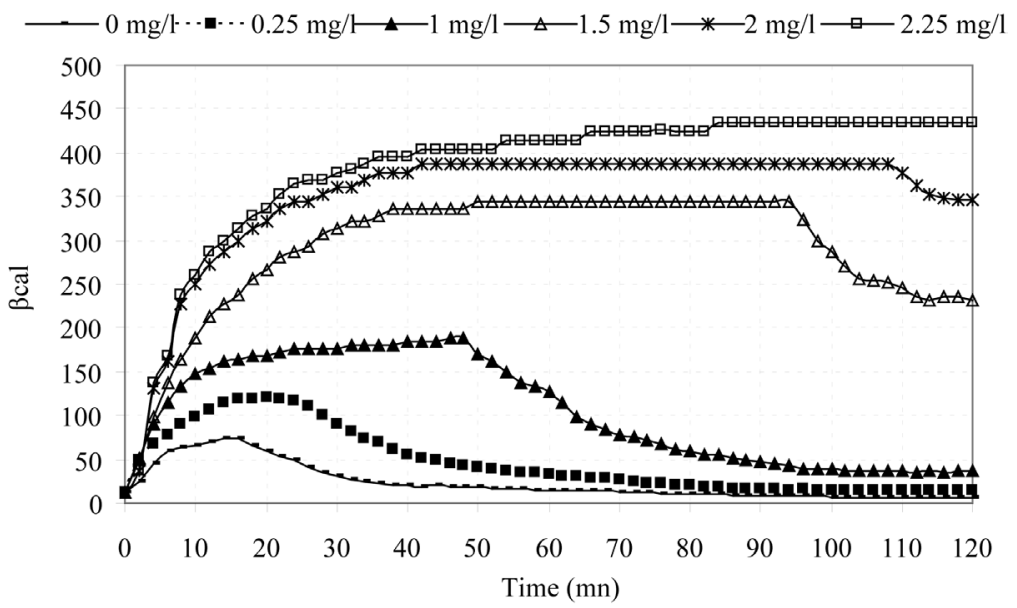

Figure 8. Variation of the coefficient of supersaturation according to the time of the tests with natural water added with the increasing concentrations in phosphate fertilizer. 
Table 3. Germination time (Tg), $\mathrm{pH}$ of germination $\left(\mathrm{pH}_{\mathrm{g}}\right)$, coefficient of supersaturation overlooked to the calcite $(\beta$ calcite) and precipitation speed of the natural water added with the increasing quantities of phosphate fertilizer.

\begin{tabular}{|c|c|c|c|c|c|c|c|}
\hline \multirow{2}{*}{$\begin{array}{c}\text { Concentration } \\
\mathrm{mg} / \mathrm{L}\end{array}$} & \multirow{2}{*}{$\operatorname{Tg}(\mathrm{mn})$} & \multirow{2}{*}{$\mathrm{pH}_{\mathrm{g}}$} & \multirow{2}{*}{$\beta$ cal } & \multicolumn{2}{|c|}{ Diffusional calcite } & \multicolumn{2}{|c|}{ Reddy calcite } \\
\hline & & & & $\mathrm{K}_{\mathrm{D}}\left(\mathrm{mn}^{-1}\right)$ & $\mathrm{R}^{2}$ & $\mathrm{~K}_{\mathrm{R}}\left({ }^{\circ} \mathrm{F}^{-1} \cdot \mathrm{mn}^{-1}\right)$ & $\mathrm{R}^{2}$ \\
\hline 0.00 & 16 & 8.27 & 73.62 & $1.14 \times 10^{-2}$ & 0.997 & $6.74 \times 10^{-4}$ & 0.991 \\
\hline 0.25 & 26 & 8.5 & 120.31 & $8.89 \times 10^{-3}$ & 0.992 & $4.56 \times 10^{-4}$ & 0.998 \\
\hline 1.00 & 48 & 8.68 & 189.23 & $8.03 \times 10^{-3}$ & 0.990 & $3.53 \times 10^{-4}$ & 0.994 \\
\hline 1.50 & 94 & 8.94 & 344.35 & $7.91 \times 10^{-3}$ & 0.956 & $3.10 \times 10^{-4}$ & 0.970 \\
\hline 2.00 & 110 & 8.99 & 386.36 & $2.11 \times 10^{-3}$ & 0.980 & $7.39 \times 10^{-5}$ & 0.981 \\
\hline 2.25 & - & - & - & - & - & - & - \\
\hline
\end{tabular}

- The speed of scaling decreases according to the content of the inhibitor introduced into the solution.

- The $\mathrm{pH}$ at the point of germination of the treated water increases with the concentrations of the inhibitor, it moves from 8.27 per $0 \mathrm{mg} / \mathrm{L}$ to 8.99 per $2 \mathrm{mg} / \mathrm{L}$. The fall of the $\mathrm{pH}$ appears clearly in the test without inhibitor, whereas when the concentrations are increased, the fall becomes less remarkable.

- The rate of supersaturation at the time of germination undergoes an increase after the introduction of the scale preventive. Then it varies from 73.62 for the test with $0 \mathrm{mg} / \mathrm{L}$ to 386.36 per $2 \mathrm{mg} / \mathrm{L}$ of scale preventive.

- The precipitation follows a diffusional model in the test without inhibitor. It is modeled by the Reddy model for tests with the inhibitor.

\section{Conclusions}

The Legrand-Poirier-Leroy method allowed us to determine the position of the irrigation waters compared to calco-carbonic equilibrium. The LCGE technique, based on the accelerated formation of deposits of calcium carbonate under the effect of degassing of the studied water, allowed us to evaluate the power scaling of these irrigation waters.

Indeed, the application of this technique on the pure calco-carbonic water $\left(40^{\circ} \mathrm{F}\right)$, allowed us to essentially bring out the inhibiting character of scaling of the phosphate fertilizer used by farmers.

The experimental results allowed us to conclude that germination time in the case of the calco-carbonic solution at $40^{\circ} \mathrm{F}$ is 12 minutes without inhibitor; the addition of $2 \mathrm{mg} / \mathrm{L}$ of phosphate fertilizer to the latter makes it possible to avoid the precipitation of calcium carbonate under the conditions of the experiment, which is the total inhibition of scaling. The study carried out on the water of agriculture showed that $2.25 \mathrm{mg} / \mathrm{L}$ of the phosphate fertilizer completely inhibits the precipitation of calcium carbonate under the conditions of the experiment.

Thus, the inhibiting effect of scaling on agricultural water of this synthetic fertilizer is highlighted. It allows the stabilization of the encrusting water, whose thermodynamic and kinetic characteristics induce effectively the precipitation of calcium carbonate.

\section{References}

[1] Hadfi, A., Eddaoudi, H., El Hadek, M., Ghorbel, A. and Driouiche, A. (2011) The Characterization of Scaling Power of Irrigation Water of the Agricultural Region in Large Agadir. Physical and Chemical News, 57, 44-50.

[2] Roques, H. (1964) Static and Kinetic Study of the Systems Gas Carbonic-Water-Carbonate of Calcium. Thesis, Toulouse.

[3] Dedieu, L., Hort, C., Martin Dominguez, A., Rola, M. and Roques, H. (1994) Contribution to the Study of Scale Formation. I: Generality and Methods of Study. Tribune de l'eau, 47, 3-19.

[4] Hort, C., Martin Dominguez, A., Rabut, C. and Roques, H. (1995) Contribution to the Study of Scaling Phenomena. 2nd Part: The Kinetics of Crystal Growth. Tribune de l'eau, 48, 31-46.

[5] Elfil, H. and Roques, H. (2001) Role of Hydrate Phases of Calcium Carbonate on the Scaling Phenomenon. Desalination, 137, 177-186. http://dx.doi.org/10.1016/S0011-9164(01)00216-8

[6] Reddy, M.M. (1977) Crystallization of Calcium Carbonate in the Presence of Trace Concentrations of PhosphorusContaining Anions: I. Inhibition by Phosphate and Glycerophosphate Ions at $\mathrm{pH} 8.8$ and $25^{\circ} \mathrm{C}$. Journal of Crystal Growth, 41, 287-295. http://dx.doi.org/10.1016/0022-0248(77)90057-4 
[7] Berner, A. (1980) Crystallisation and Dissolution Kinetics of $\mathrm{CaCO}_{3}$ in Seawater. Acts of Congress "CrystallisationDeformation-Dissolution" of Carbonates, Bordeaux, 17-18 November 1980, 33.

[8] Simkiss, K. (1964) Phosphates as Crystal Poisons of Calcification. Biological Reviews, 39, 487-504. http://dx.doi.org/10.1111/j.1469-185X.1964.tb01166.x

[9] Stumm, W. and Leckie, J.O. (1970) Phosphate Exchange with the Sediments; Its Role in the Productivity of Surface Waters. Proceedings of $5^{\text {th }}$ International Water Pollution Research Conference, San Francisco, 1970, 3-26. 